\title{
Yield increases due to fungicide control of leaf blotch diseases in wheat and barley as a basis for IPM decision-making in the Nordic-Baltic region
}

\author{
Marja Jalli • Janne Kaseva • Björn Andersson • Andrea Ficke • Lise Nistrup-Jørgensen • \\ Antanas Ronis • Timo Kaukoranta • Jens-Erik Ørum • Annika Djurle
}

Accepted: 8 July 2020 /Published online: 28 July 2020

(C) The Author(s) 2020

\begin{abstract}
Fungal plant diseases driven by weather factors are common in European wheat and barley crops. Among these, septoria tritici blotch (Zymoseptoria tritici), tan spot (Pyrenophora tritici-repentis), and stagonospora nodorum blotch (Parastagonospora nodorum) are common in the Nordic-Baltic region at variable incidence and severity both in spring and winter wheat fields. In spring barley, net blotch (Pyrenophora teres), scald (Rhynchosporium graminicola, syn. Rhynchosporium commune) and ramularia leaf spot (Ramularia collo-cygni) are common
\end{abstract}

Electronic supplementary material The online version of this article (https://doi.org/10.1007/s10658-020-02075-w) contains supplementary material, which is available to authorized users.

M. Jalli $(\bowtie) \cdot J$. Kaseva $\cdot$ T. Kaukoranta

Natural Resources Institute Finland (Luke), Tietotie 4, FI-31600 Jokioinen, Finland

e-mail: marja.jalli@luke.fi

\section{B. Andersson · A. Djurle}

Swedish University of Agricultural Sciences, Almas Allé 5, SE-75007 Uppsala, Sweden

\author{
A. Ficke \\ Bioforsk, Høgskoleveien 7, NO-1430, Ås, Norway
}

L. Nistrup-Jørgensen

Aarhus University, Forsøgsvej 1, DK-4200 Slagelse, Denmark

\section{A. Ronis}

Lithuanian Research Centre for Agriculture and Forestry, Institute of Agriculture, Instituto ave. 1, LT-58344 Kedainiai, Lithuania

\section{J.-E. Ørum}

University of Copenhagen, Rolighedsvej 25,

DK-1958 Frederiksberg C, Denmark yield limiting foliar diseases. We analysed data from 449 field trials from 2007 to 2017 in wheat and barley crops in the Nordic-Baltic region and explored the differences in severity of leaf blotch diseases between countries and years, and the impact of the diseases on yield. In the experiments, septoria tritici blotch dominated in winter wheat in Denmark and southern Sweden; while in Lithuania, both septoria tritici blotch and tan spot were common. In spring wheat, stagonospora nodorum blotch dominated in Norway and tan spot in Finland. Net blotch and ramularia leaf blotch were the most severe barley diseases over large areas, while scald occurred more locally and had less yield impact in all countries. Leaf blotch diseases, with severity $>50 \%$ at DC 73-77, caused an average yield loss of $1072 \mathrm{~kg} / \mathrm{ha}$ in winter wheat and $1114 \mathrm{~kg} / \mathrm{ha}$ in spring barley across all countries over 5 years. These data verify a large regional and yearly variation in disease severity, distribution and impact on yield, emphasizing the need to adapt fungicide applications to the actual need based on locally adapted risk assessment systems.

\section{Keywords IPM · Parastagonospora nodorum.} Pyrenophora teres $\cdot$ Pyrenophora tritici-repentis . Ramularia collo-cygni $\cdot$ Rhynchosporium graminicola . Risk assessment $\cdot$ Yield loss $\cdot$ Zymoseptoria tritici

\section{Introduction}

In the Nordic-Baltic region (Denmark, Finland, Norway, Sweden, Lithuania), three leaf blotch diseases of wheat; septoria tritici blotch (STB, caused by Zymoseptoria tritici, 
syn. Mycosphaerella graminicola), tan spot (TS, caused by Pyrenophora tritici-repentis), and stagonospora nodorum blotch (SNB, caused by Parastagonospora nodorum, syn. Phaeosphaeria nodorum), occur regularly over large areas, and affect yield. Net blotch (caused by Pyrenophora teres), scald (caused by Rhynchosporium graminicola, syn. Rhynchosporium commune) and ramularia leaf spot (RLS, caused by Ramularia collocygni), are the most common leaf blotch diseases of barley in the Nordic-Baltic countries. The incidence and severity of these foliar diseases vary between years and countries, and between regions within countries (Jalli et al. 2011; Ronis et al. 2014; Ficke et al. 2018b; Jørgensen et al. 2018). The variation in occurrence of plant diseases is usually explained by differences in climatic conditions, synchronization between pathogen arrival and the growth stage of the host crop, cultivation history, host plant resistance and agricultural practices (Shaner 1981; Hosford et al. 1987; Riaz et al. 1991; Hardwick et al. 2001; Oerke 2006; Jørgensen and Olsen 2007; Shaw et al. 2008; Wiik and Ewaldz 2009).

Wheat is grown on 2.7 million ha in the Nordic and Baltic region (Eurostat 2019). Winter wheat (WW) is mainly grown in Denmark, Sweden and Lithuania, while spring wheat (SW) dominates in Norway and Finland. Yields of WW and SW typically vary between 3.5 and 7.3 tons $\mathrm{ha}^{-1}$. The highest yields are seen in Denmark and southern Sweden, while yields are more moderate in the Baltic region and the northern areas of the Nordic countries (Eurostat 2019). While STB is the dominant leaf disease in winter wheat, SNB and TS dominate in spring wheat (Jalli et al. 2011; Djurle and Bommarco 2014; Ficke et al. 2016; Jørgensen et al. 2018). Spring barley (SB) is grown on 1.8 million ha in the Nordic-Baltic region (Eurostat 2019), while winter barley cropping is quite rare in this region, except for Denmark where it represents ca 15-20\% of the barley area (SEGES 2019). Average yields vary between 3.4 and 5.1 tons $\mathrm{ha}^{-1}$. Again, the higher yields are found in the southern areas in Denmark (Eurostat 2019). Net blotch is common, and impacts yield of barley most in Finland and Norway (Hansen and Magnus 1969; Jalli et al. 2014) while leaf rust (caused by Puccinia hordei) along with net blotch is most important in the southern areas of the Nordic Baltic region (Jørgensen et al. 2018).

Knowledge of yield losses is the basis for disease management, and is needed to determine management thresholds for integrated and economically sound plant protection strategies. Yield loss caused by plant diseases is usually defined as the quantitative difference between the attainable yield and the actual yield (Zadoks and Schein 1979). Crop loss refers to the reduction in value of the crop due to damage from insects and diseases, or other biotic or abiotic stress factors, including drought, extreme temperatures and high or low solar radiation (Oerke 2006).

Yield losses caused by plant diseases are difficult to estimate with high accuracy. Available information on yield losses caused by leaf blotch diseases in wheat and barley is mainly based on field trials where the difference in yield between an untreated control plot and a plot with fungicide treatments, that keep the crop as healthy as possible, is measured. This difference is considered the yield loss. The underlying assumption is that, except for the disease intensity, all other factors that might affect yield in the compared plots are kept similar.

With increasing disease intensities (severity or incidence), concommitantly greater yield losses are expected. An early disease outbreak that continues in the crop over a prolonged period is likely to have a greater effect on yield compared to an outbreak that starts later and has a shorter duration. Lupton (1972) showed that after ear emergence in winter wheat, more than $80 \%$ of the photosynthesis contribution to grain filling (yield) comes from the flag leaf and the ear. Later studies have defined that genotypic variability, including differences in flag leaf area, as well as growing conditions greatly affect the contribution of the ear and flag leaf to grain filling (Khaliq et al. 2008; Sanchez-Bragado et al. 2014). Keeping the flag leaf and the second uppermost leaf (F-1) free from disease is considered an important strategy to minimize yield losses caused by plant diseases. In barley, it is more important to keep the F-1 leaf and the ear healthy, since the contribution from the flag leaf is almost insiginificant due to its small size (AHDB 2018). However, the photosynthetically active radiation interception required during different grain filling periods differs, and therefore the timing of the disease outbreak and control measures have variable effects on yield (Bingham et al. 2019).

In Europe, the principles of integrated pest management (IPM) are legislated as a way of minimizing the use of pesticides (Directive 2009/128/EC 2009). For the management of leaf blotch diseases in wheat and barley, crop rotation, tillage practices, choice of cultivar, adjustments of sowing time, seed treatment, and the use of fungicides are currently available options. In IPM, 
fungicides should be used as a last resort when preventive actions have been insufficient and the applications are economically justified, based on disease management thresholds. These thresholds are defined as the density of pest populations that will economically justify the use of pesticides (Vanderplank 1963). The thresholds are usually based on disease observation, weather data and the reduction in quantity or quality of crop yield from the expected disease development (Nutter et al. 1991; Nutter et al. 1993).

It is a major challenge to define the economic injury level at which the benefit of control just exceeds its cost (Jørgensen et al. 2017). There is a poor correlation between early assessments of STB, made before growth stage DC 39 (Zadoks et al. 1974), and later yield reductions (Thomas et al. 1989); furthermore, traditional action thresholds using observed disease intensities may be unreliable predictors for fungicide applications (Paveley et al. 1997).

Thus, action thresholds for managing STB have been developed, and are mainly based on precipitation events (Tyldesley and Thomsen 1980; Te Beest et al. 2009; Wiik and Ewaldz 2009). Validation of these control thresholds over the years has often shown comparable timings (Jørgensen and Hagelskjær 2003; Burke and Dunne 2008). Although most research has been focused on developing control thresholds for STB based on precipitation, temperature may also be important, particularly when it comes to latency periods and the speed at which STB develops (Shaw 1990; Lovell et al. 2004). SNB and TS are also humidity driven diseases. In addition, temperature is very important for the development rate of TS, due to the short latency period (5-8 days) of the disease (Riaz et al. 1991).

Different disease management thresholds and methods to estimate the need for fungicide applications are currently used in the Nordic-Baltic region. In Denmark and Sweden, a set of thresholds are guiding farmers when fungicide treatments may be appropriate in wheat and barley. As an example, at least four rain-days $(>1 \mathrm{~mm})$ from growth stage DC 32 onwards, are needed before application of fungicide against STB is recommended (Henriksen et al. 2000; Aiéro et al. 2018). In Norway, regression models are used to predict leaf blotch diseases in wheat and barley based on precipitation periods and disease intensity (King et al. 1983; Elen 2007). Finnish farmers have access to the WisuForecast service which utilizes farm-specific field plot data as well as data on temperature, precipitation and humidity to aid decision-making for plant protection during the growing season (Peltonen et al. 2016). In Lithuania, there are no official guidelines for fungicide treatments against leaf diseases in cereals.

The use of fungicides against leaf blotch diseases varies in the Nordic-Baltic region, with a higher frequency of treatments in both wheat and barley in the southern areas, and a lower frequency further north. Fungicides in wheat and barley against leaf blotch diseases are usually applied in the interval between stem elongation and flowering (DC 32-65). In the northern areas of the region, fungicides against leaf blotch diseases are seldom applied more than once, while in the southern part two to three applications are more common in winter wheat, while barley is most commonly treated once and rarely more than twice. During the stem elongation stage, flag leaf emergence and heading, fungicide treatments are broadly aimed for control of leaf blotch diseases but also for control of powdery mildew and rust diseases. During flowering, treatments are mainly applied to control diseases with shorter latency periods, which include rust diseases, tan spot and Fusarium head blight but also to protect the crop as long as possible from leaf blotch diseases (Djurberg, Erlund, Nielsen, Semaskiene, Solberg, personal communications).

Fungicide treatments do not always result in an economical net return for the grower (Hardwick et al. 2001; Wiik and Rosenqvist 2010; EL Jarroudi et al. 2015; Djurle et al. 2018) and may have negative environmental impacts. Understanding the actual yield loss caused by leaf blotch diseases of wheat and barley in the northern region of Europe is critical for the sustainable and economical use of fungicides. Based on a common dataset collected across Denmark, Finland, Norway, Sweden and Lithuania over several years, we: i) investigated the occurrence and severity of the main leaf blotch diseases and their impact on yield losses in wheat and barley in the Nordic-Baltic region, and ii) described the annual and regional variation in disease severity and yield losses. We discuss the potential need for disease forecasting models as a means of reducing the yield losses caused by leaf blotch diseases, while avoiding unjustified fungicide treatments.

\section{Materials and methods}

Yield losses attributable to leaf blotch diseases in WW, SW and SB were calculated using yield and disease observations from randomized block field trials conducted between 2004 and 2017 in Denmark (DK), 
Finland (FI), Lithuania (LT), Norway (NO) and Sweden (SE) (Fig. 1). In most cases, the data originated from fungicide efficacy trials representing a range of broadspectrum fungicides with different modes of actions and from different fungicide groups, but all with a primary purpose of controlling leaf blotch diseases. The trial sites represent northern European climate conditions. The long-term average daily temperature in April September at the data collection sites varies between 10.7 and $14.6{ }^{\circ} \mathrm{C}$ and the number of rain days between 40 and 57 (Klein Tank et al. 2002).

The respective cultivar resistance to leaf blotch diseases, when recorded, varied from a moderate resistant to susceptible. For trials in Denmark and Sweden, cultivar resistance mainly describes the resistance to STB, while in other countries it describes a more general response to leaf blotch diseases. The growing season shortens the further north the trial site in the NordicBaltic region and generally growth stages are attained earlier in Denmark and southern Sweden compared to in Norway, Finland, mid-Sweden and Lithuania. WW is normally sown in September or early October - varying across the region, similarly SB and SW are sown from March to May, and earlier in the southern areas compared to the more northern areas of the region.

The disease observations selected for the analyses were taken at the flag leaf and booting stage (DC 3951) and at the milk development stage (DC 73-77). In wheat, STB, SNB, TS, powdery mildew, yellow rust and wheat leaf rust were recorded, and in barley net blotch, scald, RLS, powdery mildew and barley brown rust were recorded. In Denmark, Lithuania and Sweden, severities were assessed visually as the estimated percentage of the leaf area diseased on individual leaf levels. In WW and SW, the average percentage severity on the two uppermost leaves was used. Disease severity on the second leaf was used for SB. In Finland and Norway, the percentage disease severity was the average of that estimated on the three uppermost leaves.

A measure of the combined severity of simultaneously occurring leaf blotch diseases was calculated as the sum of their severities both at DC 39-51 and DC 73-77. The sums were categorized into the following severity classes: 0-1, 1.01-5, 5.01-20, 20.01-50 and 50.01-100\% diseased leaf area. The class limits were determined by the need to allocate a sufficient number of observations in each class and to create disease classes, which were well-related to yield losses. All field trials where the severity of powdery mildew or rust diseases exceeded 5\% were excluded in order to avoid confounding influence from these diseases on the results.

Yield data was adjusted to $15 \%$ moisture content. Yield loss was defined as the difference in yield between an untreated control treatment and a treatment where a broad-spectrum fungicide was applied to the foliage. For the estimation of yield loss in wheat, control treatments and
Fig. 1 The data collection sites in each country are represented by the blue dots

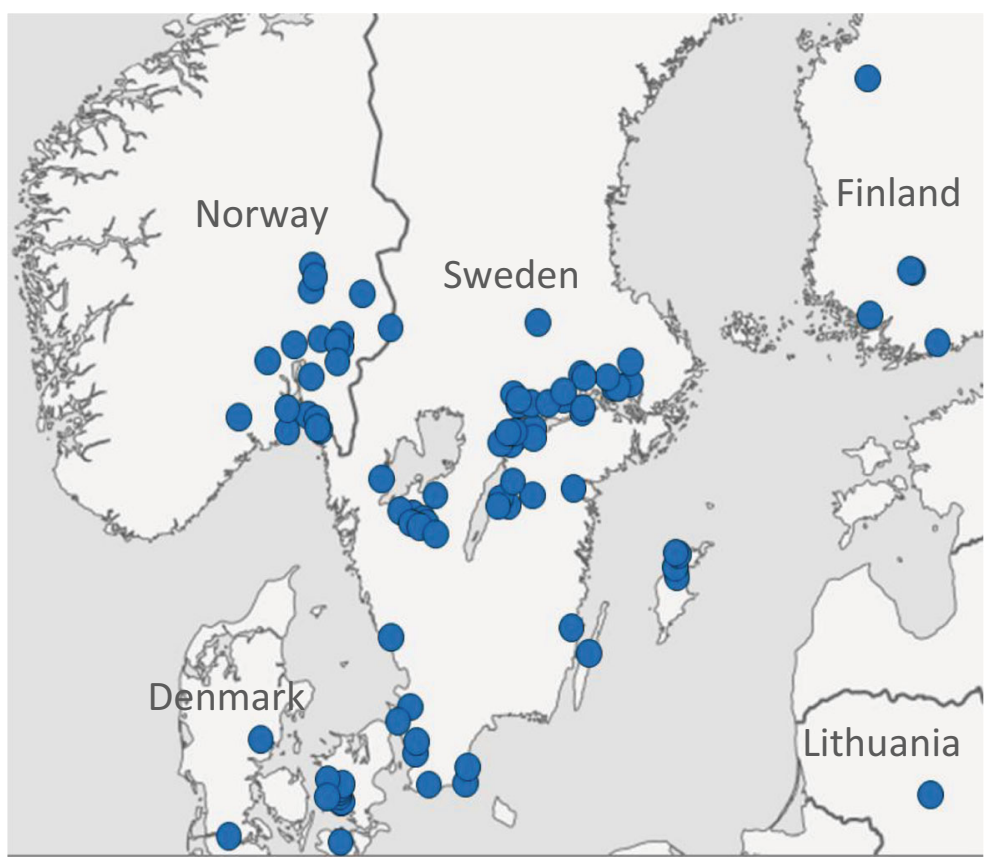


treatments with one (SW) or two (WW) fungicide applications were selected. In barley, control treatments and treatments with one fungicide application were included. Each treatment consisted of two to four replicates. The number of years, trials, trial locations and the cultivars used varied among countries (Table 1).

Since the distributions of yield losses $\left(\mathrm{kg} \mathrm{ha}^{-1}\right)$ in the data pooled over countries was approximately normal, and some losses were negative, linear mixed models without transformations were used. All models were fitted using the restricted maximum likelihood (REML) estimation method. Degrees of freedom were calculated using the Kenward-Roger method. The assumptions of the models were tested by plotting the residuals against fitted values.

As noted above, the summed leaf blotch severities for each trial were classified into five categories because the relationship between yield increase and disease severity was not linear in all cases. The main effect of the severity class was treated as a fixed effect in each model. Estimated means of the classes were compared using the TukeyKramer post hoc test $(\alpha=0.05)$. Trial-based effects within disease severity classes and cultivars were both considered as random effects. Thus, the models had the form:

yield loss $=$ severity class + cultivar + country $\times$ year

$$
\times \text { trial (severity class) }
$$

Yield loss is defined as the yield difference between those plots receiving fungicide treatment and the untreated control plots of a cultivar in a trial; Severity class is the severity class of the sum of leaf blotch diseases in an untreated control treatment; Cultivar is one of cultivars used in trials; Country is one of the five countries; Year is a year in which the trial was conducted. Because the violation of the assumption of linearity was not crucial in all cases, and the normality of the residuals were mostly achieved with random structure (without severity class), the results of severities as a continuous predictor $(0-100 \%)$ is included in the supplementary material. The analyses were performed using the GLIMMIX procedure SAS/STAT V9.3 (SAS Institute Inc. 2012).

\section{Results}

Disease severity data

In Denmark, Sweden and Lithuania, STB and TS were observed on WW. In all five years the severity of STB was greater in Denmark, than in Sweden and Lithuania (Table 2). TS was observed in fewer trials than STB in Denmark and Sweden. In those trials where TS was observed in Denmark, the disease was severe. However, TS is not widespread in Denmark, and the results in Table 2 represent trials with reduced tillage and where wheat was the previous crop. SNB was not observed on

Table 1 Years data were collected, number of locations ( $\mathrm{N}$ loc), cultivars ( $\mathrm{N}$ cult), observations ( $\mathrm{N}$ obs), cultivar resistance to leaf blotch diseases $\left(\mathrm{Cv}\right.$ res) and the mean yield loss $\left(\mathrm{kg} \mathrm{ha}^{-1}\right)$ in trials in the different Nordic-Baltic countries

\begin{tabular}{llllllll}
\hline Crop $^{\text {a }}$ & Country $^{\text {b }}$ & Years & N loc & N cult & N obs $^{\text {c }}$ & Cv res $^{\text {d }}$ & Mean yield loss kg ha $^{-1}$ \\
\hline WW & DK & $2007-2017$ & 13 & 22 & 246 & MS-S & 1208 \\
WW & FI & $2013-2017$ & 3 & 3 & 3 & MS & 596 \\
WW & LT & $2004-2017$ & 1 & 13 & 97 & ND & 903 \\
WW & SE & $2012-2017$ & 40 & 16 & 80 & MS & 529 \\
SW & FI & $2007-2017$ & 5 & 9 & 27 & MS-S & 448 \\
SW & NO & $2010-2016$ & 26 & 6 & 50 & MR-S & 702 \\
SB & DK & $2006-2017$ & 12 & 26 & 187 & MS-S & 625 \\
SB & FI & $2007-2017$ & 4 & 9 & 33 & MR-S & 1160 \\
SB & LT & $2008-2017$ & 1 & 9 & 44 & ND & 925 \\
SB & NO & $2013-2017$ & 16 & 28 & 158 & MS-S & 749 \\
SB & SE & $2012-2017$ & 62 & 22 & 104 & ND & 551 \\
\hline
\end{tabular}

${ }^{\mathrm{a}} \mathrm{WW}$ : winter wheat, SW: spring wheat, SB: spring barley

${ }^{\mathrm{b}}$ DK: Denmark, FI: Finland, LT: Lithuania, NO: Norway, SE: Sweden

${ }^{\mathrm{c}} \mathrm{Obs}=$ one mean across replicates in one trial

${ }^{\mathrm{d}} \mathrm{MS}=$ medium susceptible, $\mathrm{S}=$ susceptible, $\mathrm{MR}=$ medium resistant, $\mathrm{ND}=$ not detected 
Table 2 Mean severity (\%) and standard deviation (SD) of septoria tritici blotch (STB) and tan spot (TS) in winter wheat in Denmark (DK), Lithuania (LT) and Sweden (SE) at growth stage DC 73-77 from 2013 to 2017 . $N$ = number of trials

\begin{tabular}{lllllllll}
\hline & & \multicolumn{3}{l}{ STB } & & \multicolumn{2}{l}{ TS } \\
\cline { 8 - 9 } \cline { 7 - 8 } Year & Country & N & Mean & SD & & N & Mean & SD \\
\hline 2013 & DK & 23 & 23.3 & 20.6 & 4 & 28.5 & 34.9 \\
2014 & DK & 16 & 32.1 & 23.0 & 1 & 16.3 & 0 \\
2015 & DK & 15 & 36.0 & 21.5 & 1 & 76.9 & 0 \\
2016 & DK & 28 & 26.3 & 27.7 & 5 & 47.3 & 10.3 \\
2017 & DK & 15 & 45.9 & 29.6 & 2 & 71.3 & 13.3 \\
2013 & LT & 8 & 11.4 & 8.9 & 6 & 1.6 & 0.9 \\
2014 & LT & 7 & 7.9 & 7.3 & 7 & 7.5 & 8.6 \\
2015 & LT & 6 & 11.0 & 11.1 & 6 & 2.9 & 1.5 \\
2016 & LT & 11 & 21.9 & 15.4 & 13 & 18.8 & 13.3 \\
2017 & LT & 8 & 7.8 & 4.7 & 8 & 14.8 & 7.8 \\
2013 & SE & 9 & 13.3 & 12.3 & 2 & 15.3 & 20.9 \\
2014 & SE & 13 & 12.5 & 9.2 & 1 & 4.0 & 0 \\
2015 & SE & 10 & 16.1 & 11.4 & 1 & 4.3 & 0 \\
2016 & SE & 5 & 4.9 & 6.9 & 9 & 7.4 & 6.6 \\
2017 & SE & 9 & 3.1 & 3.8 & 8 & 1.7 & 2.8 \\
\hline
\end{tabular}

WW (Table 2). In Finland on SW, TS was the major leaf blotch disease while the incidence and severity of SNB was higher in Norway than in Finland. STB was observed only at low severity in Norway (Table 3 ).

In $\mathrm{SB}$, net blotch was the most severe disease in most countries. The highest severities were observed in
Finland, and the lowest in Norway. Scald was widespread in all seasons in Finland, while more severe scald was recorded in Denmark, Sweden and Norway only in 2015. RLS was most severe in Denmark in 2013-2017 (Table 4), while only sporadic outbreaks were observed in the other countries.

\section{Yield responses}

The yield losses caused by leaf blotch diseases in the field trials were greatest in absolute terms in Denmark in WW (Table 1). At the same production level, losses in winter wheat were lower in Sweden (Figs. 2, 4). Although yields were much lower in SW than in WW, relative yield losses were as high in SW in Finland and Norway as in WW in Denmark, which was approximately $15 \%$ (Figs. 3,4).

Disease severities observed at DC 39-51 failed to explain WW yield losses (Fig. 5). When measured at DC 73-77, yield losses tended to increase as disease severity increased. Losses of 446, 806, 818, 1010 and $1072 \mathrm{~kg} \mathrm{ha}^{-1}$ were related to severity classes $0-1,1.01-$ 5, 5.01-20, 20.01-50 and 50.01-100\%, respectively (Fig. 6, Table 5). The average yield in the WW trials was $8970 \mathrm{~kg} \mathrm{ha}^{-1}$. It is notable that even when the disease severity was as low as $0-1 \%$, there was a yield loss measured relative to the untreated control.

In SW (average yield $5740 \mathrm{~kg} \mathrm{ha}^{-1}$ ), the association between yield loss and disease severity was significant when yield losses in severity classes $0-1 \%$ and $2-5 \%$
Table 3 Mean severity (\%) and standard deviation (SD) of tan spot (TS), stagonospora nodorum blotch (SNB) and septoria tritici blotch (STB) in spring wheat in Finland (FI) and Norway (NO) at growth stage DC 73-77 from 2013 to 2017 . $\mathrm{N}=$ number of trials. Missing values: the disease was not detected

\begin{tabular}{|c|c|c|c|c|c|c|c|c|c|c|}
\hline \multirow[b]{2}{*}{ Year } & \multirow[b]{2}{*}{ Country } & \multicolumn{3}{|c|}{ TS } & \multicolumn{3}{|c|}{ SNB } & \multicolumn{3}{|c|}{ STB } \\
\hline & & $\mathrm{N}$ & Mean & SD & $\mathrm{N}$ & Mean & Std Dev & $\mathrm{N}$ & Mean & SD \\
\hline 2013 & FI & 3 & 18.8 & 11.9 & 3 & 0 & 0 & 3 & 0 & 0 \\
\hline 2014 & FI & 1 & 38.8 & & 2 & 0 & 0 & 2 & 0 & 0 \\
\hline 2015 & FI & 2 & 0 & 0 & 3 & 0 & 0 & 3 & 0 & 0 \\
\hline 2016 & FI & 1 & 47.5 & & 2 & 0 & 0 & 2 & 0 & 0 \\
\hline 2017 & FI & 1 & 72.5 & & 1 & 0 & & 1 & 0 & \\
\hline 2013 & $\mathrm{NO}$ & & & & 6 & 26.9 & 36 & & & \\
\hline 2014 & $\mathrm{NO}$ & 3 & 3 & 4.4 & 2 & 0 & 0 & 2 & 1 & 1.4 \\
\hline 2015 & NO & 1 & 0 & & 1 & 22.5 & & 1 & 2 & \\
\hline 2016 & NO & 4 & 0.7 & 0.9 & 6 & 25.1 & 35.8 & 3 & 4.2 & 7.2 \\
\hline
\end{tabular}


Table 4 Mean severity (\%) and standard deviation (SD) of net blotch, scald and ramularia leaf spot (RLS) in barley in Denmark (DK), Finland (FI), Lithuania (LT), Norway (NO) and Sweden
(SE) at DC 73-77 from 2013 to $2017 . \mathrm{N}=$ number of trials. Missing values: the disease was not detected

\begin{tabular}{|c|c|c|c|c|c|c|c|c|c|c|}
\hline \multirow[b]{2}{*}{ Year } & \multirow[b]{2}{*}{ Country } & \multicolumn{3}{|c|}{ Net blotch } & \multicolumn{3}{|c|}{ Scald } & \multicolumn{3}{|c|}{ RLS } \\
\hline & & $\mathrm{N}$ & Mean & SD & $\mathrm{N}$ & Mean & SD & $\mathrm{N}$ & Mean & SD \\
\hline 2013 & DK & 13 & 56.0 & 10.3 & 13 & 0.0 & 0.0 & 13 & 25.1 & 16.1 \\
\hline 2014 & DK & 14 & 3.4 & 4.4 & 14 & 1.1 & 3.1 & 14 & 6.5 & 9.4 \\
\hline 2015 & DK & 20 & 7.1 & 15.9 & 20 & 7.6 & 11.3 & 20 & 10.9 & 14.1 \\
\hline 2016 & DK & 11 & 8.7 & 12.2 & 11 & 0.0 & 0.0 & 11 & 12.2 & 11.3 \\
\hline 2017 & $\mathrm{DK}$ & 17 & 7.8 & 17.7 & 17 & 0.0 & 0.0 & 17 & 25.7 & 19.6 \\
\hline 2013 & FI & 3 & 30.3 & 42.0 & 3 & 15.0 & 26.0 & 0 & 0 & 0 \\
\hline 2014 & FI & 3 & 38.5 & 43.1 & 3 & 4.1 & 7.1 & 0 & 0 & 0 \\
\hline 2015 & FI & 3 & 61.7 & 41.6 & 3 & 10.4 & 18.0 & 0 & 0 & 0 \\
\hline 2016 & FI & 3 & 52.3 & 45.5 & 3 & 17.5 & 30.3 & 0 & 0 & 0 \\
\hline 2017 & FI & 3 & 51.5 & 45.5 & 3 & 11.3 & 19.6 & 0 & 0 & 0 \\
\hline 2013 & $\mathrm{LT}$ & 5 & 14.1 & 4.4 & & & & 3 & 8.4 & 2.1 \\
\hline 2014 & LT & 1 & 8.3 & & & & & & & \\
\hline 2015 & $\mathrm{LT}$ & 1 & 2.9 & & & & & & & \\
\hline 2016 & $\mathrm{LT}$ & 5 & 58.0 & 2.7 & & & & & & \\
\hline 2017 & LT & 3 & 2.2 & 2.4 & & & & 3 & 36.6 & 54.1 \\
\hline 2013 & $\mathrm{NO}$ & 6 & 0.3 & 0.3 & 4 & 0.6 & 0.6 & & & \\
\hline 2014 & NO & 3 & 0.0 & 0.1 & 2 & 0.0 & 0.0 & & & \\
\hline 2015 & $\mathrm{NO}$ & 8 & 1.0 & 1.1 & 10 & 6.7 & 13.7 & & & \\
\hline 2016 & $\mathrm{NO}$ & 5 & 3.2 & 1.4 & 5 & 0.0 & 0.0 & & & \\
\hline 2017 & $\mathrm{NO}$ & 5 & 0.4 & 0.4 & & & & & & \\
\hline 2013 & SE & 12 & 15.7 & 15.4 & 11 & 0.8 & 1.5 & 7 & 2.2 & 4.0 \\
\hline 2014 & SE & 11 & 8.4 & 14.2 & 10 & 0.0 & 0.1 & 10 & 0.4 & 0.8 \\
\hline 2015 & SE & 10 & 8.6 & 10.4 & 10 & 9.0 & 5.9 & 10 & 0.3 & 1.0 \\
\hline 2016 & SE & 3 & 6.2 & 10.8 & 3 & 0.0 & 0.0 & 4 & 4.6 & 5.3 \\
\hline 2017 & SE & 13 & 15.0 & 23.5 & 5 & 0.2 & 0.3 & 8 & 1.2 & 3.1 \\
\hline
\end{tabular}

were compared with higher severity classes (Table 5). Losses were 421, 311, 1014, 833 and $1147 \mathrm{~kg} \mathrm{ha}^{-1}$ for the five respective classes between 0 and 1 and 50.01$100 \%$ (Fig. 7). As with WW, even in those field plots with severity class $0-1 \%$, there was measurable yield loss.

SB had an average yield of $6600 \mathrm{~kg} \mathrm{ha}^{-1}$. There was variation in yield loss in all countries and loss distributions were rather symmetric (Fig. 8). Both absolute and relative losses were higher in Finland and Lithuania than in the other countries (Figs. 8,9). Losses were 422, 475, 601,692 and $1114 \mathrm{~kg} \mathrm{ha}^{-1}$ in severity classes $0-1$ to $50.01-100 \%$, respectively (Fig. 10). Yield losses were significantly greater in the two highest disease severity classes (Table 5).

The models having severity as a continuous predictor showed quite similar results. The slopes of disease severities differed from zero $(p<0.007)$ for SW and SB at DC 73-77, but not for WW at either DC 39-51 or DC 73-77 $(p=0.17)$ (Supplementary Table 1).

\section{Discussion}

This study is the first comprehensive overview, using historical data from multiple years of field trials, on the occurrence of leaf blotch diseases in wheat and barley 


\section{The SAS System}

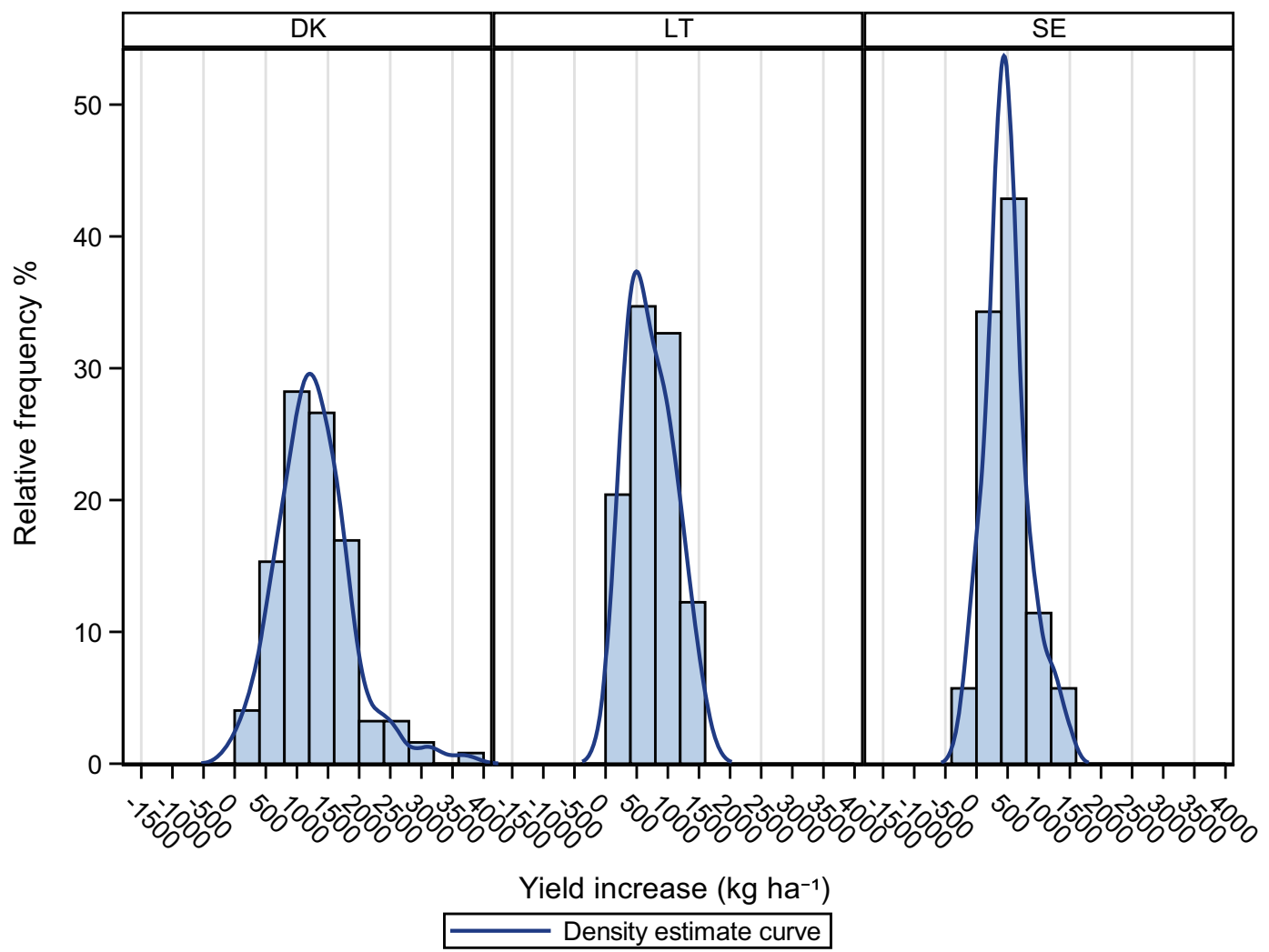

Fig. 2 Distribution of winter wheat yield increases calculated as the difference in yield between fungicide treated and untreated control plots in field trials in Denmark (DK), Lithuania (LT) and Sweden (SE) from 2013 to 2017

and their effects on yield in the Nordic-Baltic region. The data collected during this study showed regional and annual variations in the dominant leaf blotch diseases of WW, SW and SB.

Similar to the results we observed, previous regional studies showed that prevalence of wheat diseases vary across the European region (Jørgensen et al. 2014). The variation is related to the interaction between disease cycles and climatic conditions, susceptibility of the major cultivars, cultivation history and cropping practices including sowing time and tillage (Fones and Gurr 2015). STB is currently the major leaf blotch disease of WW in the Nordic-Baltic region, while SNB and TS are the major leaf blotch diseases in SW. Prevalence of SNB has fallen below visual detection levels in much of the Maritime zone since the mid-1980's, as STB became more prevalent. The shift is linked to changes in the cultivars used as well as to other changes in the cropping practices and environment (Shaw et al. 2008). Similarly, the occurrence of TS has been linked to specific cropping practices including reduced tillage and wheat monoculture (Jørgensen and Olsen 2007; Jalli et al. 2011). The severe TS we observed also reflects changes in cropping practices, and is not representative of the whole Nordic-Baltic wheat regions.

Net blotch was the most common leaf blotch disease in the 181 SB trials studied in the Nordic-Baltic region. This is congruent with observations from previous studies, which have shown that the average net blotch incidence in Finnish fields increased from 60 to $86 \%$ over the last 40 years (Jalli et al. 2011). Even though cultivar resistance has increased in the Nordic region (Jalli 2010), net blotch causes regular yield losses in the northern areas of the region. Scald was observed in most of the trial countries except in Lithuania. Besides the climatic conditions, the incidence of scald is related to the location of the trial plots and availability of primary inoculum, which has limited ability for spread (ca. $1 \mathrm{~m}$ 


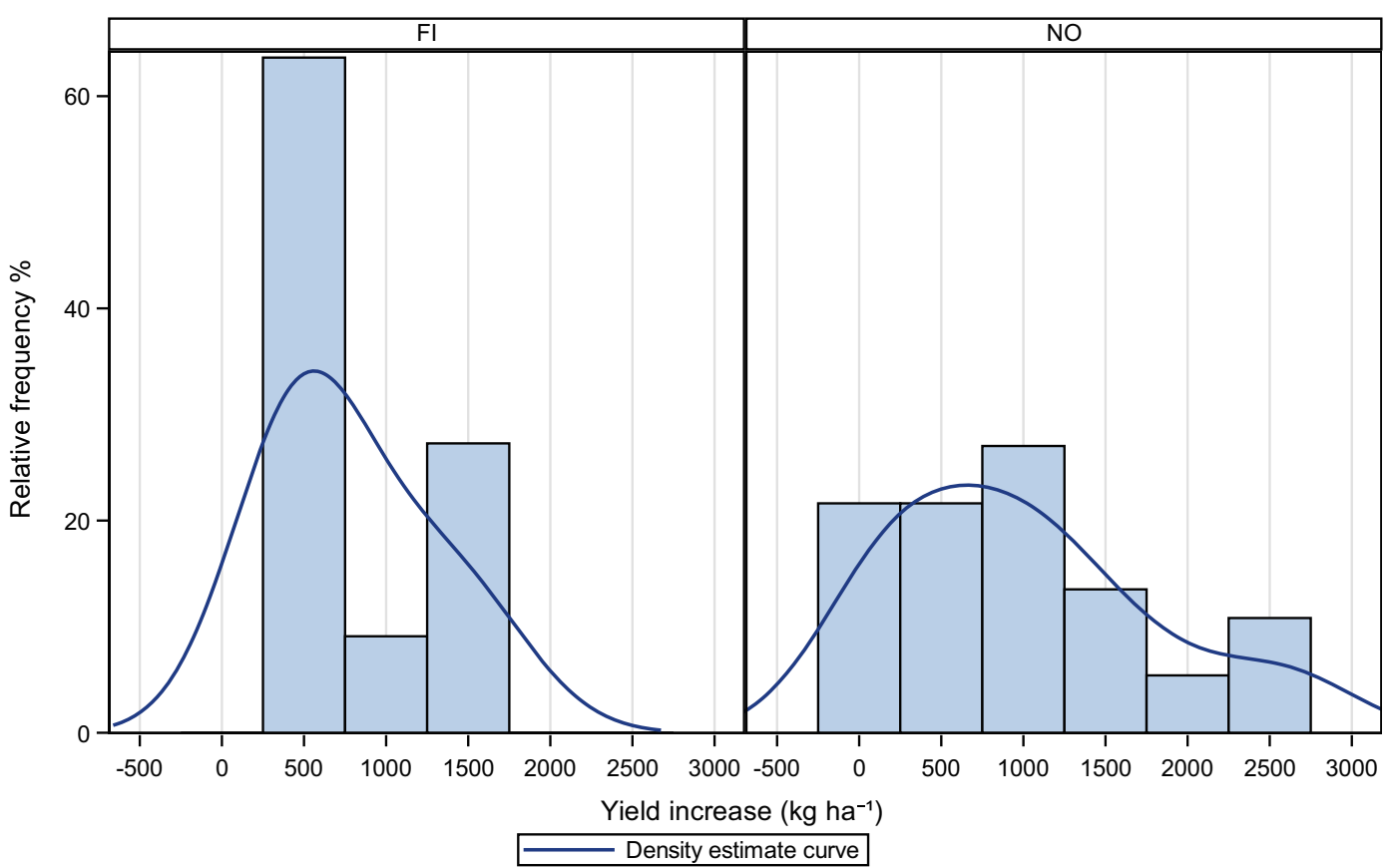

Fig. 3 Distribution of spring wheat yield increases calculated as the difference in yield between fungicide treated and untreated control plots in field trials in Finland (FI) and Norway (NO) from 2013 to 2016

from the infection source) during the growing season (Fitt et al. 1986). Symptoms of RLS are visible at later crop development stages (DC 72-85, Havis et al. 2015), but late infections may not be observable at DC 73-77. RLS was not observed on SB at the trial sites in Finland and Norway, but is reported in both countries (Havis et al. 2015).

Even though average long-term weather is rather similar in Denmark, Finland, Lithuania, Norway and Sweden, there are considerable annual and site-specific differences (data not shown). Wiik and Ewaldz (2009) have shown that mean monthly air temperature and precipitation explained $>50 \%$ of the variation in yield and wheat leaf blotch diseases between years; precipitation in May was found to be the main weather factor explaining leaf blotch disease intensity. With SB, conditions including cool and humid weather, together with primary inoculum are the main factors affecting leaf blotch disease incidence (Shaner 1981). Net blotch does not require rain events, since dewfall alone can trigger infection and disease development, while scald typically requires rain events for substantial development of the disease.

Despite the methods followed for the fungicide trials being similar in all participating countries due to the commonly used EPPO guidelines (EPPO 2019), there were some differences in disease rating. In Finland and Norway, disease severities were based on an average of the uppermost leaves while in Denmark, Lithuania and Sweden disease severities were per leaf. It may be assumed that mixed infections occurred, and that only the dominant diseases were assessed in such cases. The challenge of assessing mixed infections has been reported recently in a study where 325 leaf samples were tested for presence of SNB, TS or STB using both visual assessments and qPCR. In $61 \%$ of the samples, the PCR method showed that the pathogens causing at least two of the diseases were present, while visual assessments in nearly all cases only reported one of the diseases (Jørgensen et al. 2018). Due to the differences in observation methods as well as the challenge in achieving accurate estimates based on visual observations, it is essential to note that the disease severity classes we used are ultimately based on estimates using the methods described earlier, and thus caution is needed if attempts are made to generalise or apply these results under other circumstances.

Bearing in mind the limited data from each of the different trial areas, and the use of visual disease assessments, it is essential to stress that the disease severities in this study relate to specific areas and those diseases present with the highest incidence. Another important 


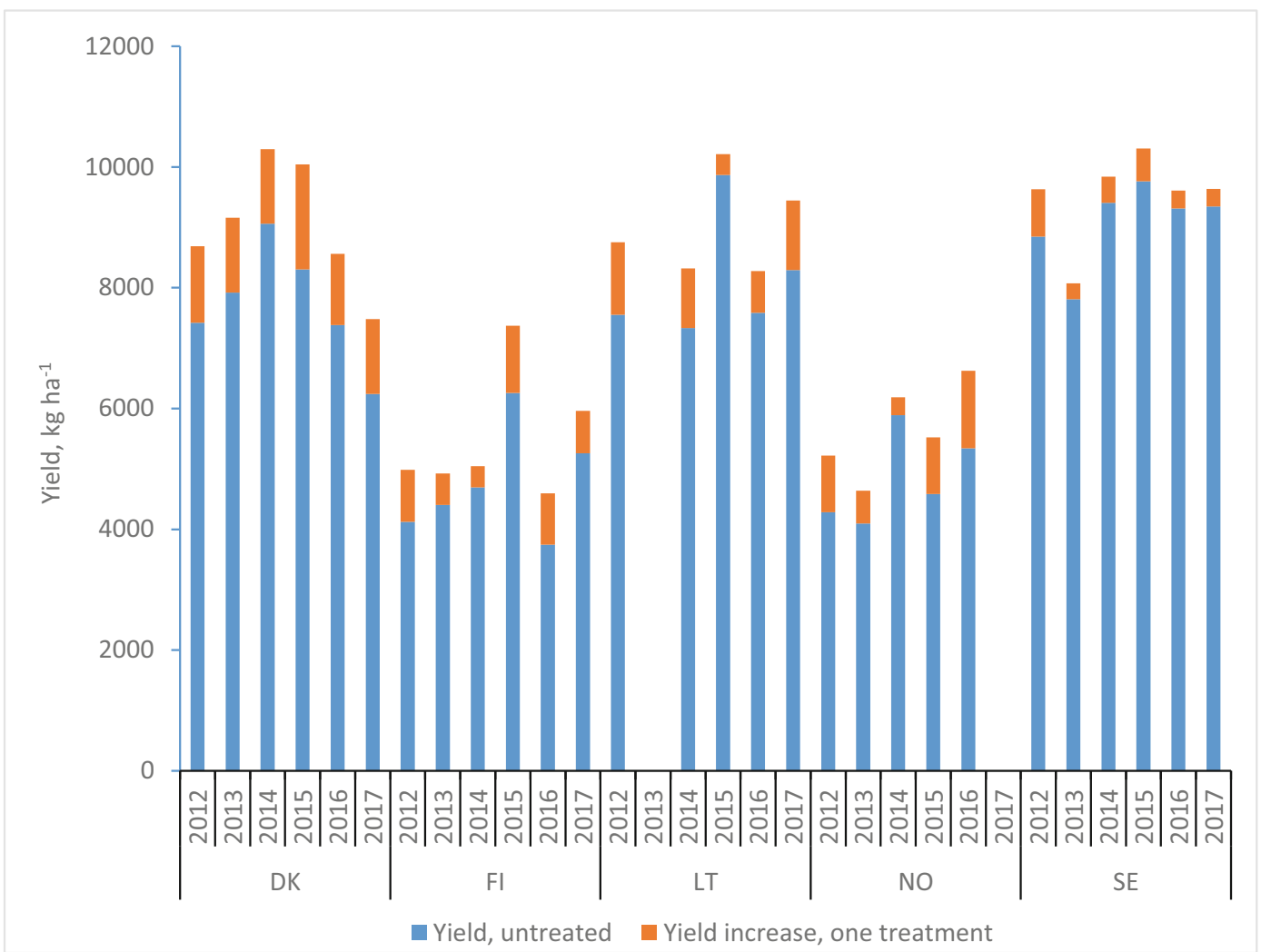

Fig. 4 Winter wheat (Denmark - DK, Lithuania - LT, Sweden - SE) and spring wheat (Finland - FI, Norway - NO) yield (kg/ha) in untreated trial plots and the yield increase achieved with one fungicide treatment from 2012 to 2017

point to consider is that the timing of the last assessment can have a major impact on the disease intensity being scored. The disease severity assessed at DC 77 can be very different from the severity assessed at DC 73 , which might be just a few days earlier.

The results of our study indicate a positive yield response after one fungicide treatment in wheat, which was variable depending on leaf blotch severity. In WW, yield responses from fungicides treatments range between 0.5 and 2 tons ha ${ }^{-1}$, which is equivalent to a yield response of 5-20\%, depending on soil types, cultivar, season and region. Yield losses in the range of 5-15\% have previously been reported from the region (Jalli et al. 2014; Jørgensen et al. 2018), and these have been confirmed by our current study. The responses differ between countries with the highest yield increases achieved in Denmark (Fig. 2 and Fig. 3). In SB, the yield response was generally lower in the countries with the highest yields: Denmark and Sweden. In Finland and Lithuania, the yield increases were considerably higher, and especially so in Finland which is associated with the most severe leaf blotch observed.
The differences in yield response between different field trials and locations are consistent with previous research. Byamukama et al. (2019) showed that location and cultivar are the main factors influencing yields in fungicide-treated WW trials. In our study, cultivars with resistance ranging from moderately resistant to susceptible were cultivated at the different locations and in different years. Other biotic and abiotic stresses such as drought may have influenced the yield responses resulting from application of fungicides. Nason et al. (2007) showed that water use efficiency of wheat plants was improved slightly by quinone outside inhibitors (QoI) fungicides under normal growing conditions, but was reduced in drought-stressed plants. This observation, and other stress factors affecting plant growth, might explain the few cases in our study which showed a negative yield response to fungicide treatment. Also, some negative responses due to random variation in yield is possible with a large number of trials, as we had in our study.

The results show an association between disease severity at the milk ripening stage and yield loss in all 
The SAS System

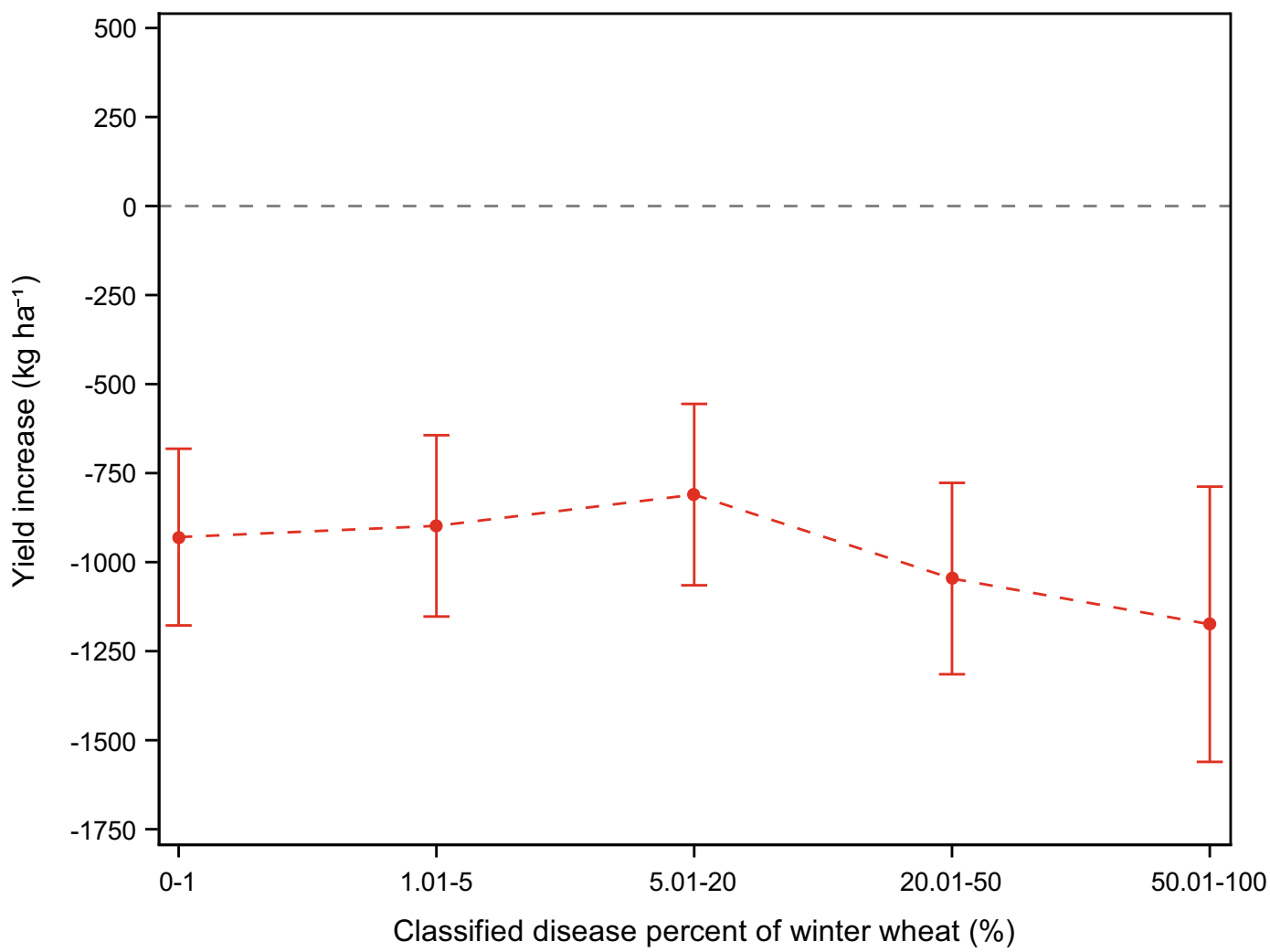

Fig. 5 Estimated yield response in winter wheat by leaf blotch severity class (total disease severity of STB, SNB and TS at growth stages DC 39-51) in Denmark, Lithuania and Sweden. Bars show 95\% confidence limits. Observations where severity of

studied crops. This is in agreement with results of an Australian study which demonstrated that severity of TS and SNB on the two uppermost leaves at later growth stages are good indicators of yield loss (Bhathal et al. 2003). The variation in different disease severity classes corresponding to yield losses was smaller in WW and $\mathrm{SB}$, which had 2.5 and 3.5 fold more observations compared to SW, respectively. In our study, the yield response in the most severe class $(50.01-100 \%)$ was similar in WW, SW and SB (1072, 1147 and $1114 \mathrm{~kg} \mathrm{ha}^{-1}$, respectively).

As discussed by Nutter et al. (1993), the measured yield gain from using fungicide control does not provide information on the actual loss from disease. In our study, positive yield responses without severe leaf blotch were observed, possibly due to control of rust and mildew present at low severity; but a yield gain at low disease severity could also be due to growth-promoting activity powdery mildew and rusts was $>5 \%$ were excluded. The classes from lowest to highest disease severity include 48, 37, 32, 38 and 13 observations, respectively

of some of the fungicides applied, particularly the QoIproducts, which have been shown to improve photosynthetic capacity (Bartlett et al. 2002). However, the growth-promoting effect of fungicides is likely smaller than the direct disease control effect of the fungicides. The data presented is based on trials with one and two fungicide treatments applied to WW, and only one fungicide treatment applied to SW and SB. The fungicide treatments most likely did not provided complete control of the diseases and therefore the actual loss we calculated is likely to be a conservative figure when compared to the actual loss caused by leaf blotch diseases in the Nordic-Baltic region.

Even though disease assessments and agronomic treatments were made in a systematic and controlled way, there was much variation in the yield response, disease severity, and the interaction. It is likely that the variation among farmers' fields is even greater due to 
The SAS System

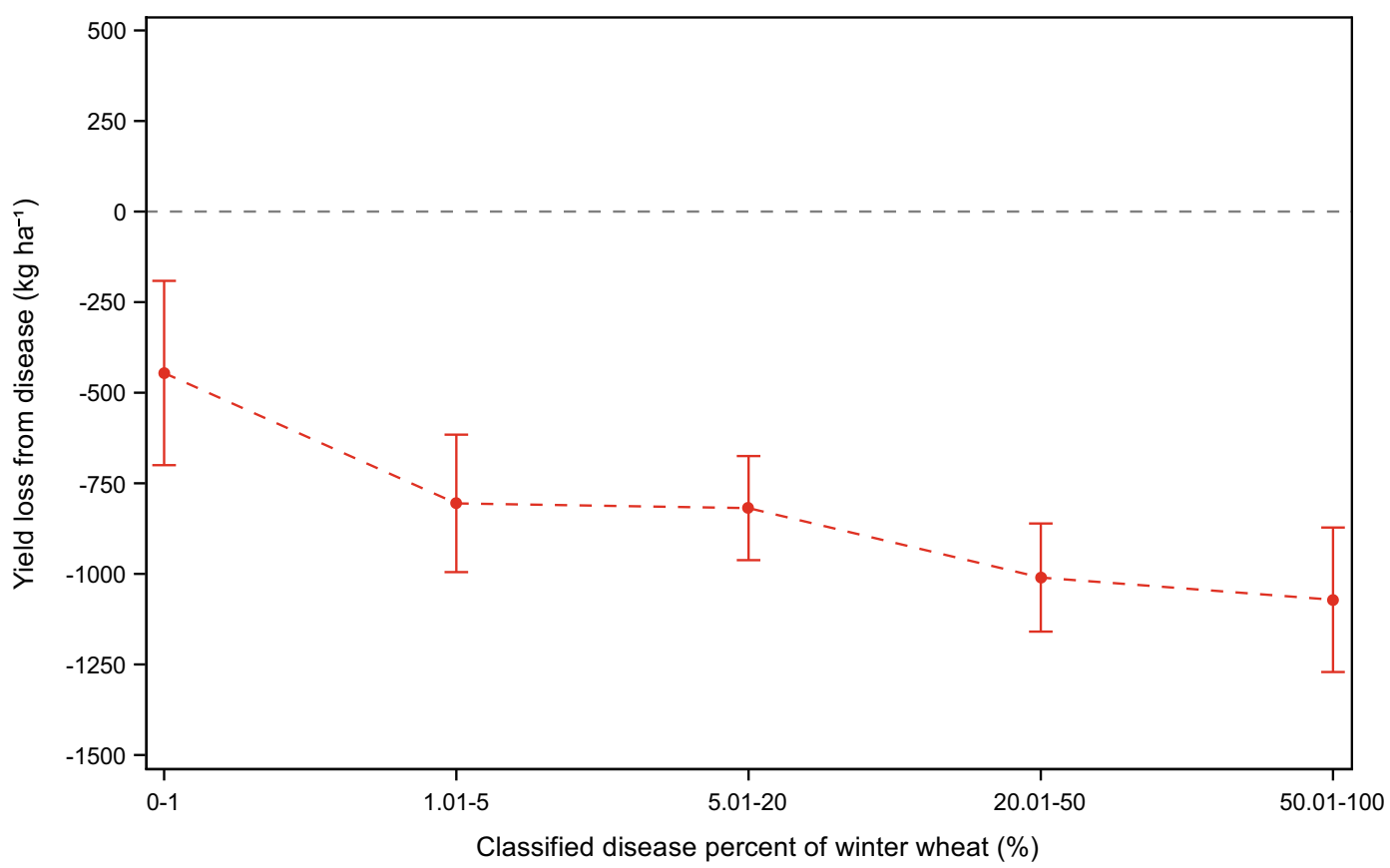

Fig. 6 Estimated yield response in winter wheat by leaf blotch severity class (total severity of STB, SNB and TS at growth stages DC 73-77) in Denmark, Lithuania and Sweden. Bars show 95\% confidence limits. Observations where severity of powdery

more variety in cropping practice, soil types, etc. than we had in our trial sites. As a consequence of the complexity of the agricultural system, where plants

Table 5 Least squares means of yield loss differences between leaf blotch disease severity classes (lower minus higher severity class as 'Mean diff'), their standard error (SE) and $P$ value (P). $P$ values of multiple comparisons were calculated using a Tukey- mildew and rusts was $>5 \%$ were excluded. The classes from lowest to highest disease severity include 20, 45, 98, 93 and 52 observations, respectively

and diseases are not the only components, there cannot be one simple relationship between disease severity and yield. The same disease severity may result in very

Kramer mean separation test $(\alpha=0.05)$. Positive values of means differences in yield indicate greater yield loss as the leaf blotch severity class increases

\begin{tabular}{|c|c|c|c|c|c|c|c|c|c|c|}
\hline \multirow[t]{2}{*}{ Disease severity class $\%^{\mathrm{a}}$} & \multirow[t]{2}{*}{ Class comparison $\%$} & \multicolumn{3}{|c|}{ Winter wheat } & \multicolumn{3}{|c|}{ Spring wheat } & \multicolumn{3}{|c|}{ Spring barley } \\
\hline & & Mean diff & $\mathrm{SE}$ & $\mathrm{P}$ & Mean diff & $\mathrm{SE}$ & $\mathrm{P}$ & Mean diff & $\mathrm{SE}$ & $\mathrm{P}$ \\
\hline $0-1$ & $1.01-5$ & 328 & 177 & 0.068 & -110 & 295 & 0.712 & 53 & 112 & 0.638 \\
\hline $0-1$ & $5.01-20$ & 319 & 166 & 0.059 & 593 & 229 & 0.013 & 179 & 102 & 0.082 \\
\hline $0-1$ & $20.01-50$ & 444 & 169 & 0.010 & 412 & 221 & 0.069 & 271 & 112 & 0.017 \\
\hline $0-1$ & $50.01-100$ & 608 & 186 & 0.002 & 726 & 294 & 0.017 & 693 & 138 & $<.0001$ \\
\hline $1.01-5$ & $5.01-20$ & -9 & 120 & 0.942 & 703 & 276 & 0.014 & 127 & 100 & 0.208 \\
\hline $1.01-5$ & $20.01-50$ & 116 & 124 & 0.350 & 522 & 270 & 0.059 & 218 & 110 & 0.05 \\
\hline $1.01-5$ & $50.01-100$ & 281 & 142 & 0.053 & 836 & 332 & 0.015 & 640 & 136 & $<.0001$ \\
\hline $5.01-20$ & $20.01-50$ & 125 & 105 & 0.240 & -181 & 195 & 0.357 & 91 & 96 & 0.343 \\
\hline $5.01-20$ & $50.01-100$ & 290 & 128 & 0.027 & 133 & 275 & 0.631 & 513 & 125 & $<.0001$ \\
\hline $20.01-50$ & $50.01-100$ & 164 & 127 & 0.202 & 314 & 268 & 0.247 & 422 & 120 & 0.001 \\
\hline
\end{tabular}

${ }^{\text {a }}$ Percentage of leaf blotch diseased leaf area. In WW and SW, the average percentage severity on the two uppermost leaves was used. Disease severity on the second leaf was used for SB. In FI and NO, the percentage disease severity was the average of the three uppermost leaves 
The SAS System

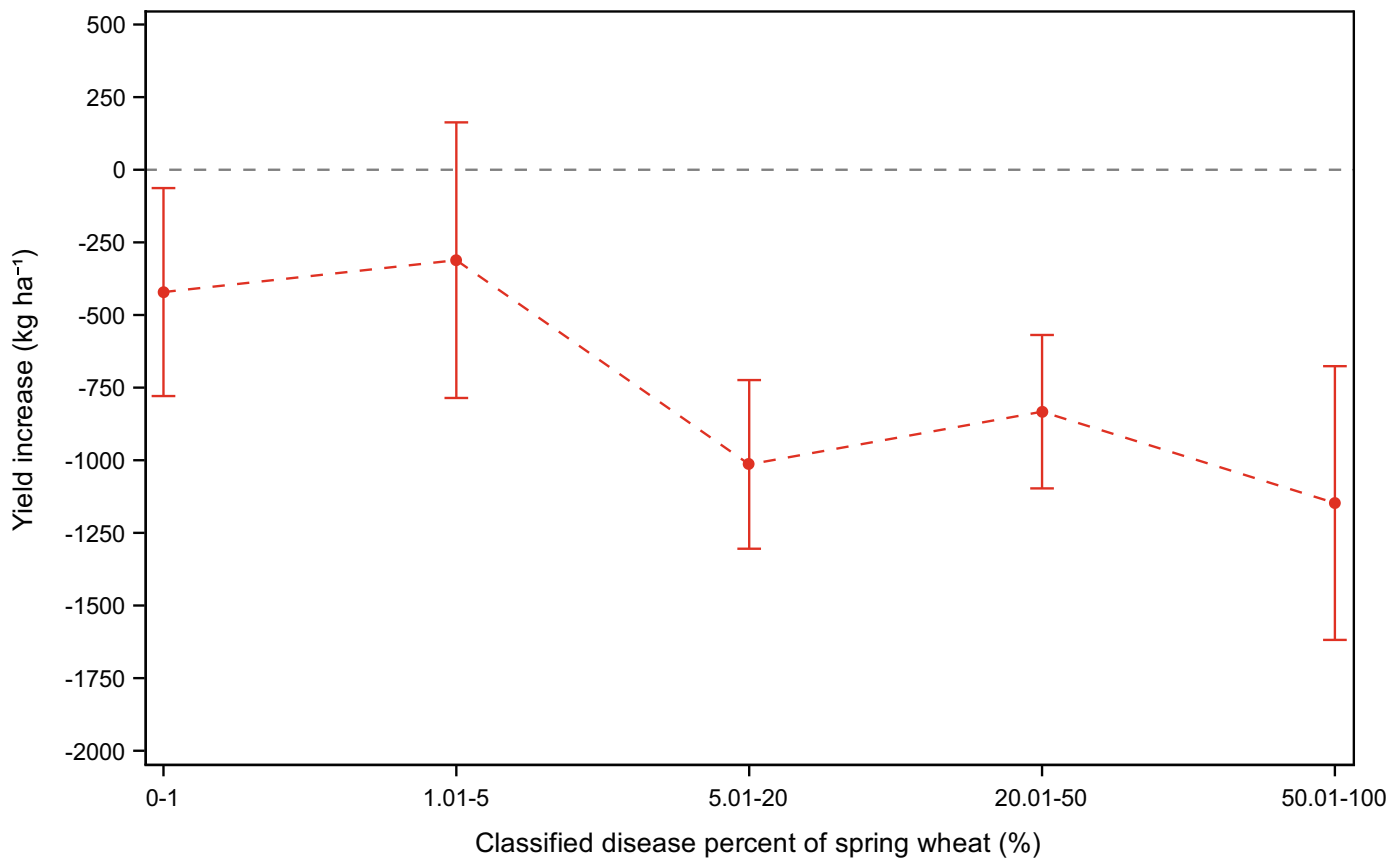

Fig. 7 Estimated yield response in spring wheat by leaf blotch severity class (total severity of STB, SNB and TS at growth stage DC 73-77) in Finland and Norway. Bars show 95\% confidence limits. Observations where severity of powdery mildew and rusts

different yield losses from one year to another: among other factors, the length of the ripening period, the defoliation experienced, and a cultivars' tolerance to leaf blotch might influence impact on yield (Waggoner and Berger 1987; Ficke et al. 2018a). Nonetheless, the results demonstate that we can determine yield impact of the main leaf blotch diseases over a large production area, in this case the Nordic-Baltic region, which can be the basis for reliable prediction of local disease risk and potential yield loss.

Ideally, predictions regarding disease development and projected impact on yield should be made in good time to allow fungicide applications to preserve yield, usually at DC 37-55. However, our studies indicate that there is no association between yield loss and disease severities at DC 39-51. This is supported by the results of Bhathal et al. (2003), who showed that it is not possible to determine how early season infection affects wheat leaf blotch disease development. The weather following early assessments will determine the disease progress until anthesis and maturity. Methods was $>5 \%$ were excluded. The classes from lowest to highest disease severity include 12, 7, 16, 19 and 8 observations, respectively

to reduce the uncertainty associated with predicting future disease severity are being developed, but often the specific disease intensity, and especially the yield loss, remains highly unpredictable, due to the effect of many factors other than diseases (Te Beest et al. 2013). Thus, the decision to use fungicides should be based on possible risk of disease development, which is a function of disease presence, cultivar resistance, and weather conditions before and after fungicides can be applied, while taking into account a farmer's experiences, and local knowledge from extension services. Another approach would be to base the yield loss predictions on the probabilities for fungicide treatments to give a marginal return under specified weather conditions, presence of diseases and cultivation practices as exemplified by Djurle et al. (2018).

Fungicides should be used only when preventive actions have failed to maintain disease severities at levels that are acceptable to the grower (EU 2019). The use of fungicides varies in the Nordic-Baltic region, with a higher frequency of 


\section{The SAS System}

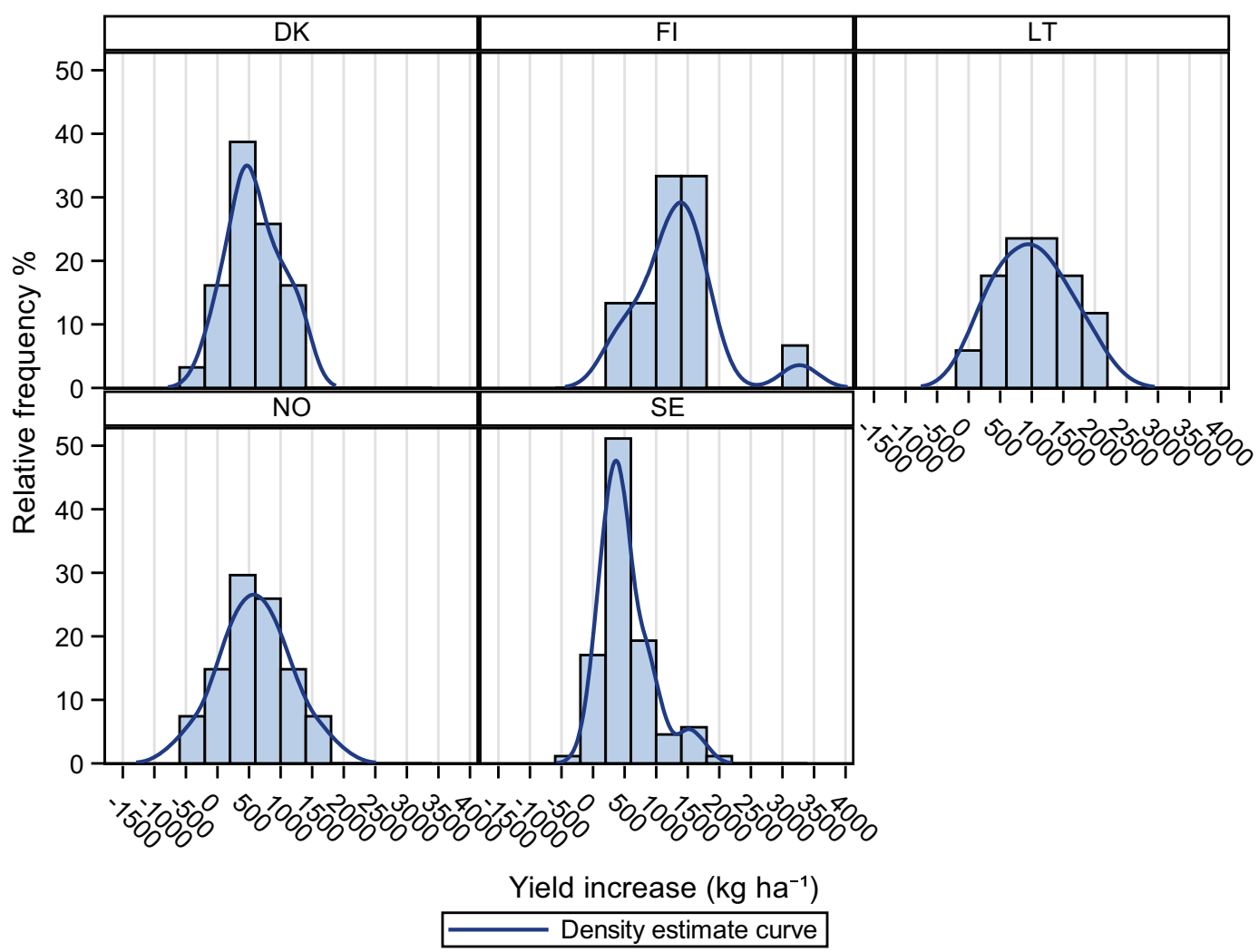

Fig. 8 Distribution of spring barley yield increases calculated as the difference in yield bewtween fungicide treated and untreated control plots in field trials in Denmark (DK), Finland (FI), Lithuania (LI), Norway (NO) and Sweden (SE) from 2013 to 2017

applications in the southern areas and a lower frequency further north. While in some areas questions related to the number of treatments, doses and timings are important, the question in other areas can be whether to apply fungicides or not. In WW, data from four seasons of pesticide use in Denmark has shown that the intensity of use varies significantly across the country and between farm types. In larger farms the intensity of pesticide use, including the use of fungicides, is higher compared to smaller farms (Jørgensen et al. 2019). Between 2010 and 2013, most of the EU Member States recorded an increase in the average production area per farm. The average size of a European farm increased by $11.8 \%$ resulting from an $11.5 \%$ fall in the number of farms and a $0.7 \%$ fall in the area under agricultural production. Relating this information to the Danish data
(Jørgensen et al. 2019) raises the concern for appropriate tools to better assess the need for fungicide applications, especially to farms with larger production areas.

For economic and environmental reasons, and in accordance with IPM principles, the overall aim should be to apply fungicides only when the economic loss is sufficient to justify, i.e. exceed, the cost of the treatment. The results we present demonstrate variation in yield increases associated with fungicide applications (Fig. 2). When considering the costs of fungicide applications, the number and cost of treatments and the grain price must be taken into account; at least $25-50 \%$ of the trials included in this study did not result in a profitable response (a $>500 \mathrm{~kg} / \mathrm{ha}^{-1}$ yield increase). Similarly, a study of $350 \mathrm{WW}$ trials in Sweden between 1996 and 2011 showed that $26-46 \%$ of the trials where 


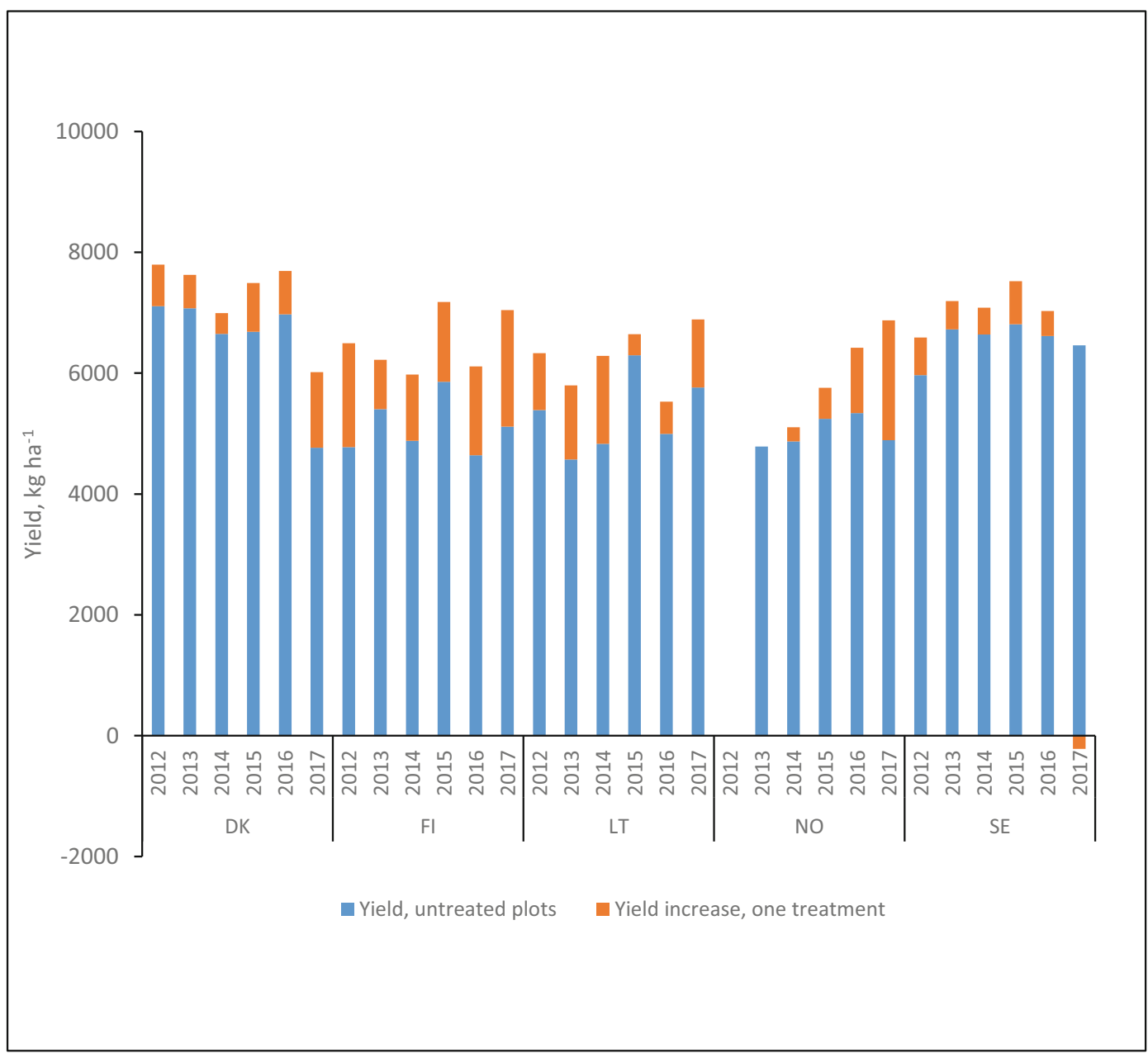

Fig. 9 Spring barley yield $(\mathrm{kg} / \mathrm{ha})$ in untreated trial plots and yield increase achieved with one fungicide treatment from 2012 to 2017 in Denmark (DK), Finland (FI), Lithuania (LT), Norway (NO) and Sweden (SE)

fungicide was applied did not result in a marginal return (Djurle et al. 2018). This reinforces the notion that applications of fungicides are not always profitable, which is true in commercial, on-farm situations too.

Despite many attempts to develop decision support systems and risk models, estimating and assessing specific disease risk and the subsequent yield loss during a growing season remains challenging. Thus, it is common for growers to apply more fungicides than is needed (Hardwick et al. 2001; Wiik and Rosenqvist 2010; EL Jarroudi et al. 2015). Te Beest et al. (2013) investigated the optimal dose when the aim of the farmers was to minimize the long-term average costs for plant protection. The authors argued that since the farmers cannot know the optimal input for a given year, they generally choose the more expensive option to guard against yield losses in possible severe disease epidemic seasons. This may help explain the discrepancy between long-term mean optimal dose and current field applied doses. Another approach to reduce the redundant use of fungicides may be to focus on fields with lower yields, either due to weather conditions, or issues associated with cultivation practices or soil characteristics. In such cases more input is needed to obtain economic return from fungicide treatments. However, once the disease is present, the challenge remains to define the economic injury level at which the financial benefit of chemical control justifies its cost (Jørgensen et al. 2017), particularly as development of the disease, and thus its effect on yield is uncertain. 


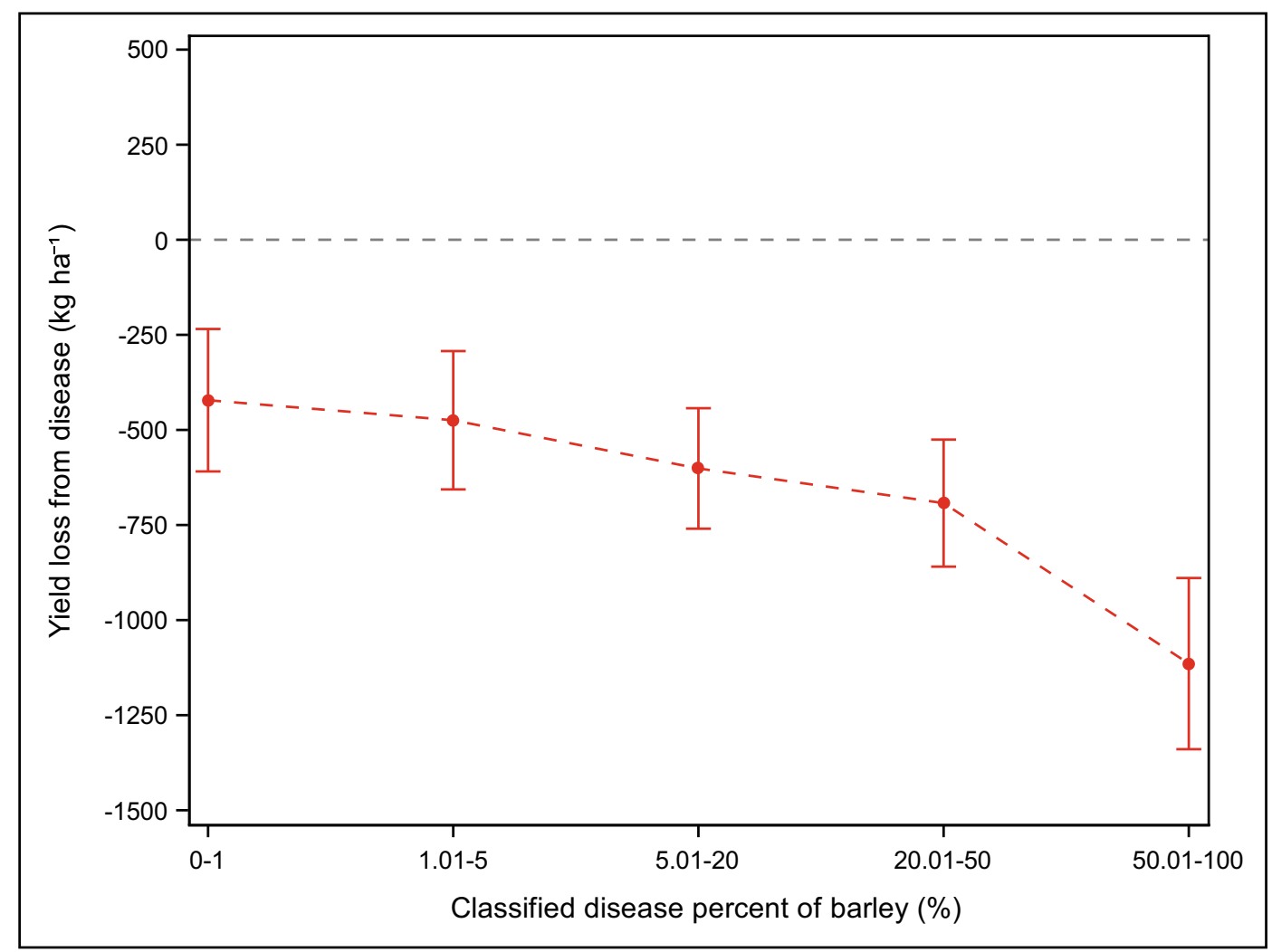

Fig. 10 Estimated yield response in spring barley by leaf blotch severity class (total severity of net blotch, scald and RLS at DC 73-77) in all Nordic-Baltic countries. Bars show 95\% confidence limits. Observations where severity of powdery mildew and rusts

\section{Conclusions}

The major leaf blotch diseases of wheat (STB, TS and $\mathrm{SNB}$ ) and barley (net blotch, scald and ramularia leaf spot) are of key importance affecting yield in the Nordic-Baltic region with major differences in effect of disease among locations and years within the different countries. The leaf blotch diseases can cause yield losses if fungicides are not applied. Due to variation in leaf blotch severity, the routinely applied fungicides are not always profitable or justified. Therefore, there is an urgent need for reliable, locally adapted disease risk prediction models to optimize the use of fungicides for wheat and barley production in the Nordic-Baltic region. Despite being able to estimate the relationship between disease severity and yield loss, management thresholds and the timing of fungicide applications are more difficult to determine as they depend on the pathogen and crop biology and development, and environmental factors. Variable economic factors and the farmers was $>5 \%$ were excluded. The classes from lowest to highest disease severity include 47, 35, 66, 48 and 23 observations, respectively

own preferences must be considered as they impact the final decision whether or when to spray.

Acknowledgements This research has been carried out as a part of the SpotIT (IT-solutions for user friendly IPM-tools in management of leaf spot diseases in cereals) project (https://www.nibio. no/en/projects/spotit) funded under the C-IPM ERA-NET. The authors thank all the project partners and the national funding organizations: Finnish Ministry of Agriculture and Forestry, Danish AgriFish Agency, Lithuanian Research Center for Agriculture and Forestry, Norwegian Research Council, and Swedish Research Council for Environment, Agricultural Sciences and Spatial Planning.

Funding Information Open access funding provided by Natural Resources Institute Finland (LUKE).

Compliance with ethical standards All authors of this manuscript are aware with the content of the article and have agreed upon its submission to European Journal Plant Pathology

- the manuscript has not been published in whole or in part elsewhere; 
- the manuscript is not currently being considered for publication in another journal;

- the manuscript is not split up into several parts to increase the quantity of submissions.

Conflict of interest The authors declare no conflict of interests.

Open Access This article is licensed under a Creative Commons Attribution 4.0 International License, which permits use, sharing, adaptation, distribution and reproduction in any medium or format, as long as you give appropriate credit to the original author(s) and the source, provide a link to the Creative Commons licence, and indicate if changes were made. The images or other third party material in this article are included in the article's Creative Commons licence, unless indicated otherwise in a credit line to the material. If material is not included in the article's Creative Commons licence and your intended use is not permitted by statutory regulation or exceeds the permitted use, you will need to obtain permission directly from the copyright holder. To view a copy of this licence, visit http://creativecommons.org/licenses/by/4.0/.

\section{References}

AHDB. (2018). Barley growth guide. https://ahdb.org. uk/knowledge-library/barley-growth-guide. Accessed 10 October 2019.

Aiéro, M., Aldén, L., Andersson, G., Arvidsson, A., Berg, G., Bölenius, E., Dinwiddie, R., Djurberg, A., Eriksson, L., Gerdtsson, A., Holmblad, J., Johansson, C., Johansson, L., Lindgren, A., Mellqvist, E. \& Norrlund, L. (2018). Bekämpningsrekommendationer - Svampar och insekter 2018. Swedish board of agriculture. https://webbutiken. jordbruksverket.se/sv/artiklar/be17.html. Accessed 10 October 2019.

Bartlett, D. W., Clough, J. M., Godwin, J. R., Hall, A. A., Hamer, M., \& Parr-Dobzanski, B. (2002). The Strobilurin fungicides. Pest Management Science, 58, 649-6622.

Bhathal, J. S., Loughman, R., \& Speijers, J. (2003). Yield reduction in wheat in relation to leaf disease from yellow (tan) spot and septoria nodorum blotch. European Journal of Plant Pathology, 109, 435-443.

Bingham, I. J., Young, C., Bounds, P., \& Paveley, N. D. (2019). In sink-limited spring barley crops, light interception by green canopy does not need protection against foliar disease for the entire duration of grain filling. Field Crops Research, 239, 124-134.

Byamukama, E., Ali, S., Kleinjan, J., Yabwalo, D. N., Graham, C., Caffe-Treml, M., Mueller, N. D., Rickertsen, J., \& Berzonsky, W. A. (2019). Winter wheat grain yield response to fungicide application is influenced by cultivar and rainfall. Plant Pathology Journal, 35, 63-70.

Burke, J. J., \& Dunne, B. (2008). Field testing of six decision support systems for scheduling fungicide applications to control Mycosphaerella graminicola on winter wheat crops in Ireland. Journal of Agricultural Science, 146, 415-428.
Directive 2009/128/EC of the European Parliament and of the Council of 21 October 2009 establishing a framework for Community action to achieve the sustainable use of pesticides. European Parliament and the Council of the European Union, EU. https://eur-lex.europa.eu/LexUriServ/LexUriServ.do?uri= OJ:L:2009:309:0071:0086:en:PDF. Accessed 10 October 2019.

Djurle, A. \& Bommarco, R. (2014). Växtskadegörare. In Vete mot nya höjder (pp. 123-132). SLU, Rapporter från jordbearbetningen, Inst. för mark och miljö, $\mathrm{Nr} 129$.

Djurle, A., Twengström, E., \& Andersson, B. (2018). Fungicide treatments in winter wheat: The probability of profitability. Crop Protection, 106, 182-189.

Jarroudi, E. L., Kouadio, M., Beyer, L., Junk, M., Hoffmann, J., Tychon, L., Maraite, B., Bock, C., \& Delfosse, P. (2015). Economics of a decision-support system for managing the main fungal diseases of winter wheat in the grand-duchy of Luxembourg. Field Crops Research, 172(2), 32-41.

Elen, O. (2007). Forecasting models of disease in barely, wheat and oilseed crops in Norway. In NJF 23rd congress 2007 trends and perspectives in agriculture. Copenhagen, June 2629, 2007. NJF Report, 3, 209-210.

EPPO. (2019). EPPO Standards - PP1 Efficacy evaluation of plant protection products: Foliar and ear diseases in cereals PP/1/ 26 (4). https://www.eppo.int/RESOURCES/eppo_ standards/pp1_list. Accessed 8 April 2020.

EU. Integrated Pest Management (IPM). (2019). Available at https://ec.europa.eu/food/plant/pesticides/sustainable_use pesticides/ipm_en. Accessed 5 April 2020.

Eurostat. (2019). https://ec.europa.eu/eurostat/data/database. Accessed 10 October 2019.

Ficke, A., Brodal, G., \& Abrahamsen, U. (2016). Bladflekksjukdommer og avlingstap I hvete-en komplisert sammenheng. NIBIO Bok, 2(1), 144-148.

Ficke, A., Cowger, C., Bergstrom, G., \& Brodal, G. (2018a). Understanding yield loss and pathogen biology to improve disease management: Septoria nodorum blotch - A case study in wheat. Plant Disease, 102, 696-707.

Ficke, A., Dieseth, J. A., Kim, M. O., \& Lillemo, M. (2018b). Bladsjukdommer I norsk hevete. Forekomst, betydning og tiltak. NIBIO Bok, 4(1), 108-115.

Fitt, B. D., Creighton, N. F., Lacey, M. E., \& McCartney, H. A. (1986). Effects of rainfall intensity and duration on dispersal of Rhynchosporium secalis conidia from infected barley leaves. Transactions of the British Mycological Society, 86, 611-618.

Fones, H., \& Gurr, S. (2015). The impact of Septoria tritici blotch disease on wheat: An EU perspective. Fungal Genetics and Biology, 79, 3-7.

Hansen, L., \& Magnus, H. (1969). Bladflekksopper på byg i Norge. Forskning og Forsøk i Landbruket, 20, 95-105.

Hardwick, N. V., Jones, D. R., \& Slough, J. E. (2001). Factors affecting diseases of winter wheat in England and Wales, 1989-98. Plant Pathology, 50, 453-462.

Havis, N. D., Brown, J. K. M., Clemente, G., Frei, P., Jedryczka, M., Kaczmarek, J., Kaczmarek, M., Matusinsky, P., McGrann, G. R., Pereyra, S., Piotrowska, M., Sghyer, H., Tellier, A., \& Hess, M. (2015). Ramularia collo-cygni-an emerging pathogen of barley crops. Phytopathology, 105, 895-904.

Henriksen, K.E., Jørgensen, L.N. \& Nielsen, G.C. (2000). PCplant protection - a Danish tool to reduce fungicide input in 
winter wheat, winter barley and spring barley in Denmark. In proceedings BCPC conference: Pests and diseases Brighton, UK, 13-16 November 2000 (pp 835-840).

Hosford, R. M., Larez, C. R., \& Hammond, J. J. (1987). Interaction of wet period and temperature on Pyrenophora tritici-repentis infection and development in wheats of differing resistance. Phytopathology, 77, 1021-1027.

Jalli, M. (2010). The virulence of Finnish Pyrenophora teres f. teres isolates and its implications for resistance breeding. MTT science, MTT Tiede 9, 99 p.

Jalli, M., Laitinen, P., \& Latvala, S. (2011). The emergence of cereal fungal diseases and the incidence of leaf spot diseases in Finland. Agricultural and Food Science, 20, 62-73.

Jalli, M., Peltonen-Sainio, P., Jauhiainen, L., Purola, T., Ingvordsen, C. \& Jorgensen, R. (2014). Diverse utilization of plant genetic resources improves durable plant disease resistance. In L.F. Groeneveld \& A. Kettunen-Praebel (Eds.) book of abstracts genetic resources for food and agriculture in a changing climate, 27-29 January 2014, Lillehammer, Norway (p. 48).

Jørgensen, L.N. \& Hagelskjær, L. (2003). Comparative field trials of various decision support systems for cereal disease control. In: Wolffhechel, H., ed., Proceedings of the crop protection conference for the Baltic Sea region, 28-29 April 2003, Poznan. DIAS report Plant Production. 96, 114-122.

Jørgensen, L. N., Hovmøller, M. S., Hansen, J. G., Lassen, P., Clark, B., Bayles, R., Rodemann, B., Flath, K., Jahn, M., Goral, T., Czembor, J. J., Cheyron, P., Maumene, D. P., Ban, C., Nielsen, R., \& G. C. \& Berg, G. (2014). IPM strategies and their dilemmas including an introduction to www.eurowheat.org. Journal of Integrative Agriculture, 13, 265-281.

Jørgensen, L. N., Kudsk, P., \& Ørum, J. E. (2019). Spraying records - Links between pesticide use pattern and crop production systems. Focus on pesticide use in winter wheat. Crop Protection, 119, 147-157.

Jørgensen, L.N., Nielsen, L., Kristjansen, H.S., Abuley, I.K. \& Nielsen, B.J. (2018). Disease attacks in 2017. In applied crop protection 2016, Aarhus University, DCA rapport Markbrug, nr. 117 (pp. 10-15).

Jørgensen, L. N., Oliver, R., Van den Bosch, F., \& Paveley, N. P. (2017). Targeting fungicides inputs according to need. Annual Review of Phytopathology, 55, 181-203.

Jørgensen, L. N., \& Olsen, L. V. (2007). Control of tan spot (Drechslera tritici-repentis) using host resistance, tillage methods and fungicides. Crop Protection, 26, 1606-1616.

Khaliq, I., Irshad, A., \& Ahsan, M. (2008). Awns and flag leaf contribution towards grain yield in spring wheat (Triticum aestivum L.). Cereal Research Communications, 36, 65-76.

King, J. E., Jenkins, J. E. E., \& Morgan, W. A. (1983). The estimation of yield losses in wheat from severity of infection by Septoria species. Plant Pathology, 32, 239-249.

Klein Tank, A. M. G., Wijngaard, J. B., Konnen, G. P., Bohm, R., Demaree, G., Gocheva, A., Mileta, M., Pashiardis, S., Hejkrlik, L., Kern-Hansen, C., Heino, R., Bessemoulin, P., Muller-Westermeier, G., Tzanakou, M., Szalai, S., Palsdottir, T., Fitzgerald, D., Rubin, S., Capaldo, M., Maugeri, M., Leitass, A., Bukantis, A., Aberfeld, R., Van Engelen, A. F. V., Forland, E., Mietus, M., Coelho, F., Mares, C., Razuvaev, V., Nieplova, E., Cegnar, T., Antonio Lopez, J., Dahlstrom, B., Moberg, A., Kirchhofer, W., Ceylan, A., Pachaliuk, O.,
Alexander, L. V., \& Petrovic, P. (2002). Daily dataset of $20^{\text {th }}$ century surface air temperature and precipitation series for the European climate assessment. International Journal of Climatology, 22, 1441-1453.

Lovell, D. J., Hunter, T., Powers, S. J., Parker, S. R., \& Van den Baosch, F. (2004). Effect of temperature on latent period of septoria leaf blotch on winter wheat under outdoor conditions. Plant Pathology, 53, 170-181.

Lupton, F. G. H. (1972). Further experiments of photosynthesis and translocation in wheat. Annals of Applied Biology, 71, 69-79.

Nason, M. A., Farrar, J., \& Bartlett, D. (2007). Strobilurin fungicides induce changes in photosynthetic gas exchange that do not improve water use efficiency of plants grown under conditions of water stress. Pest Management Science, 63, $1191-1200$.

Nutter, F. W., Teng, P. S., \& Royer, M. H. (1993). Terms and concepts for yield, crop loss, and disease thresholds. Plant Disease, 77, 211-215.

Nutter, F. W., Teng, P. S., \& Shokes, F. M. (1991). Disease assessment terms and concepts. Plant Disease, 75, 1187-1188.

Oerke, E. C. (2006). Crop losses to pests. The Journal of Agricultural Science, 144, 31-43.

Paveley, N. D., Lockley, D., Sylvester-Bradley, R., \& Thomas, J. (1997). Determinants of fungicide spray decisions for wheat. Pesticide Science, 49, 379-388.

Peltonen, S., Erlund, P., Kivipelto, J. \& Jalli, M. (2016). Viljelysuunnitteluohjelmistoon integroitu ennustepalvelu ohjaa ja tarkentaa torjuntapäätöksiä. In: Maataloustieteen Päivät 2016, 12.-13.1.2016 Viikki, Helsinki: abstract / Eds. Laura Alakukku, Nina Schulman ja Tuula Puhakainen. Suomen maataloustieteellisen seuran tiedote, 32, 94.

Riaz, M., Bockus, W. W., \& Davis, M. A. (1991). Effects of wheat genotype, time after inoculation and leaf age on conidia production of Drechslera tritici-repentis. Phytopathology, 81(10), 1298-1301.

Ronis, A., Jørgensen, L. N., Semaškienė, R., Gaurilčikienė, I., \& Ramanauskienè, J. (2014). Sensitivity of Mycosphaerella graminicola isolates to demethylation-inhibiting (DMI) fungicides. Zemdirbyste-Agriculture, 101, 177-184.

Sanchez-Bragado, R., Elazab, A., Zhou, B., Serret, M. D., Bort, J., Nieto-Taladriz, M. T., \& Araus, J. L. (2014). Contribution of the ear and the flag leaf to grain filling in durum wheat inferred from the carbon isotope signature: Genotypic and growing conditions effects. Journal of Integrative Plant Biology, 56, 444- 454.

SAS Institute Inc. (2012). SAS OnlineDoc, Version 9.3, SAS Institute, Cary, NC, USA.

SEGES. (2019). Oversigt over landsforsøgene 2019. SEGES, Danish advisory service. Agrofood Park 15, 8200 Aarhus. Table 5, page14.

Shaner, G. (1981). Effect of environment on fungal leaf blights of small grains. Annual Review of Phytopathology, 19, 273296.

Shaw, M. W. (1990). Effects of temperature, leaf wetness and cultivar on the latent period of Mycosphaerella graminicola on winter wheat. Plant Pathology, 39, 255-268.

Shaw, M. W., Bearchell, S. J., Fitt, B. D. L., \& Fraaije, B. A. (2008). Long-term relationships between environment and abundance in wheat of Phaeosphaeria nodorum and Mycosphaerella graminicola. New Phytologist, 177, 229-238. 
Te Beest, D. E., Paveley, N. D., Shaw, M. W., \& Van den Bosch, F. (2013). Accounting for the economic risk caused by variation in disease severity in fungicide dose decisions, exemplified for Mycosphaerella graminicola on winter wheat. Phytopathology, 103, 666-672.

Te Beest, D. E., Shaw, M. W., Pietravalle, S., \& Van den Bosch, F. (2009). A predictive model for early warning of Septoria leaf blotch in winter wheat. European Journal of Plant Pathology, 124, 413-425.

Thomas, M. R., Cook, R. J., \& King, J. E. (1989). Factors affecting development of Septoria tritici in winter wheat and its effect on yield. Plant Pathology, 38, 246-257.

Tyldesley, J. B., \& Thomsen, N. (1980). Forecasting Septoria nodorum on winter wheat in England and Wales. Plant Pathology, 29, 9-20.
Waggoner, P. E., \& Berger, R. D. (1987). Defoliation, disease, and growth. Phytopathology, 77, 393-398.

Vanderplank, J. E. (1963). Plant diseases: Epidemics and control. London: Academic.

Wiik, L., \& Ewaldz, T. (2009). Impact of temperature and precipitation on yield and plant diseases of winter wheat in southern Sweden 1983-2007. Crop Protection., 28, 952-962.

Wiik, L., \& Rosenqvist, H. (2010). The economics of fungicide use in winter wheat in southern Sweden. Crop Protection, 29, 11-19.

Zadoks, J. C., Chang, T. T., \& Konzak, C. F. (1974). A decimal code for the growth stages of cereals. Weed Research, 14, 415-421.

Zadoks, J. C., \& Schein, R. D. (1979). Epidemiology and plant disease management. New York: Oxford University Press. 